\title{
Utility of Dairy Products and Potency of Veterinary Ayurveda- The Ancient Medical System of India
}

\author{
MM Padhi* and SN Gaidhani \\ Central Council for Research in Ayurvedic Sciences, India
}

Submission: June 28, 2017; Published: September 15, 2017

*Corresponding author: Dr. M.M. Padhi M.D. (Ayu.) Ph.D., Former Deputy Director General \& Senior Consultant, Central Council for Research in Ayurvedic Sciences, Ministry of AYUSH, Govt. of India, 61-65, Institutional Area, Opp. 'D’ Block, Janakpuri, New Delhi - 110058, India, Tel: +-91-9868155650; Email: padhimm@gmail.com

\section{Introduction}

Ayurveda being an ancient comprehensive science of holistic health care and medicine, apart from eight specialties for human health has mentioned other branches of Ayurveda like Gau-ayurveda (related to cattle), Hasty-ayurveda (related to elephant), Asva-ayurveda (related to horses), Mrig-ayurveda (related to animals), Khag-ayurveda (related to birds), Vrikshyaayurveda (related to plants) etc. These Ayurvedic sciences were very much enriched with literature and were in practices. In the time span most of the literature and practices are almost lost and very meager are existing in some rural and tribal areas. The human health is dependent on animal health; if animal products are not up to the quality or diseased, that will affect human health. This is true for both Vegetarian and Non-Vegetarian categories. It is observed that the regular or long term use of chemical medicine has cumulative adverse effect on animals. The products of such animals are not worth for the health of human beings. This is more pertinent in developing countries.

\section{Historical background}

Following Vedas, the oldest treatises of India scribed between 4000 B.C. to 1000 B.C., Ayurveda emerged as the medical system having eight specialties like medicine (Kayachikitsa), surgery (Shalya) etc. for dealing with preventive and promotive aspects of health as well as cure of diseases of human being [1]. In Ayurvedic texts, there has been wide use of animal products recommended as dietary items or to be used as processing material, ingredients or medium of several medicinal formulations. They have been indicated to be taken preceding, along with or following administration of other herbal formulations called Anupana [2]. Usually, milk, milk products like curd, buttermilk, butter and ghee of several domesticated animals have been described as having nutritive value and also having medicated properties. The milk of indigenous cow has been described as the best substitute of human milk followed by goat. Similarly, the urine, especially that of the cow has been considered as the best having medicinal properties [3].

\section{Utility of diary products}

These products are usually derived from most of the domestic animals like cow, elephant, horse, camel, ass etc. Their medicinal properties, health benefits, harm effects of excess or irrational use and contra-indications have been described. It may be noted that all these were described when the environment or nature was free from any type of pollution in air, water or soil. There was no mechanical or chemical pollution [4]. However, the imbalance in nature or some sort of physical pollution led to disasters or epidemics in man, animal and birds. Now-adays the dairy products have also been largely affected due to hybridization, artificial fodder, polluted water/environment and ingestion of synthetic or chemical drugs [5]. Even then, utility of dairy products has increased immensely and they are intact in larger part of India and need to be protected.

In this ancient medical system Ayurveda, mostly plant parts are used as medicines while some of the metals and minerals are also used as medicines after proper detoxification/purification/ incineration procedure; in a specific recommended dose for a specific period and with proper adjuvant like honey, milk, ghee etc [6]. Milk and ghee are used as processing of medicines or to be taken along with them. Milk is a frequently used item. Cow milk in fresh form is considered best which is beneficial for growth, anabolic activities and useful in peptic diseases, tuberculosis, eye diseases, weakness etc. The curd is described as digestive and nutritious [7-9]. The buttermilk is helpful in dysentery, colitis, sprue, indigestion etc. The butter and ghee are helpful for growth, weakness, eye diseases, migraine, neuromuscular disorders. Ayurveda has a special category of products called medicated Ghrita which is useful in multiple disease conditions. The formulations consisting of milk, urine, curd, juice 
of cow dung and urine of indigenous cow called Panchagavya and medicated ghee processed with these materials has been reported to cure epilepsy and other neurological disorders [10].

\section{Veterinary ayurveda}

As far as diseases of animals and their management is concerned, Ayurveda has described about anatomical, physiological characteristics of animals, their merits, strength, common diseases and their treatment [11]. No doubt, these products have no strength in emergency condition, but are helpful to radically or significantly cure several common and chronic diseases of animals for which conventional system has no satisfactory treatment or chemical molecules render many side effects. In view of the above, the importance of rejuvenation of Veterinary Ayurveda is the prime necessity for human health.

\section{Current scenario}

On an overall survey of more than 50 books pertaining to Veterinary Ayurveda, it reveals that there are description of many herbal and poly-herbal and very few herbo-mineral formulations for animal diseases.

a. India has one of the largest livestock populations in the world. India ranked first in the case of cattle and buffalo population and accounted for 57 percent of the world's buffalo population and 16 percent of the cattle population. Of all the livestock species in India, bovines (cattle and buffalo) alone accounted for about 64 percent. Moreover, India's large livestock population has grown faster than the world's livestock population.

b. The population of different livestock species as per the 18th Livestock Census 2007 of Department of Animal Husbandry Dairying \& Fisheries, Govt. of India are as follows: Cow 199.075 million (M), Buffalo 105.343M, Sheep 71.558M, Goat $140.537 \mathrm{M}$, Pigs $11.34 \mathrm{M}$, Horse $0.611 \mathrm{M}$, Mule $0.137 \mathrm{M}$, Donkey $0.0438 \mathrm{M}$, Camel $0.517 \mathrm{M}$, Yak 0.08M, Mithun $0.26 \mathrm{M}$ and Poultry 489.0M. India ranks first with respect to buffalo, second in cattle and goats, third in sheep and fifth in poultry population in comparison to the world livestock and poultry population.

c. The contribution of livestock sector to Agriculture GDP is about $22.14 \%$ and to National GDP varied from $4.8-6.5 \%$ during the last two decades.

d. The composition of livestock population has also undergone significant transformation. In cattle, there has been a marked shift from work animals towards milch animals. As a result, the numbers of crossbred cows have increased from 3 million to 10 millions approx.

e. India is currently the largest producer of milk in the world. It produces than 110 million tones of milk annually. The per capita availability of milk increased from $112 \mathrm{gm}$ per day to about $250 \mathrm{gm}$ per day. However, the yields of Indian breeds are still far below the world average $(2,026 \mathrm{~kg}$ per year) and are just one-third to two-thirds of productivity in many developed countries.

f. Apart from being an important contributor to national income, the sector has been considered as one with high potential for alleviating poverty and unemployment in rural areas. About three-fourths of India's population and almost three-fourths of the poor population in India live in rural areas and over 70 percent of rural households have own livestock. A large majority of livestock owning households comprise of small and marginal farmers and landless households, which account for a large share of poor households.

g. In addition to being an important source of income for poor households, livestock has many other important roles. It supplies a significant portion of draft power for farming and rural transportation. Dairy products are a major source of nutritious food to million of people in India and the only acceptable source of animal protein for the large vegetarian segment of the population. The organic fertilizer produced in the livestock sector is a key factor of agricultural production and dung from livestock is a major source of cooking energy in rural areas specially among low income households. Not only is it one of the most important productive assets in the rural areas, it also serves as a critical store of wealth for farm families and an insurance mechanism to cope with household related crisis.

h. The use of antibiotics/chemical drugs which leave residues \& form a part of the food chain, is being banned \& discouraged. India already has alternative therapies/ solutions. They need to be brought into the main stream.

i. The key to success is therefore efficient, economical and reliable animal health services focusing animal health \& productivity.

\section{Status of Veterinary drug producing industry in the country}

In ancient India, due to use of animals in agriculture, transportation, food and their role in battle field, a lot of studies were done to innovate medicines for their diseases as for man. As such the descriptions of medicine in classics written in Sanskrit or regional languages are also available [12]. Apart from these, several formulation have also been in vogue and in practice traditionally called folklore claims. In keeping the animals healthy, Indian Veterinary Drug Producing Industry has taken a big leap and has contributed towards treatment of the new emerging diseases. Today, in India we have more than 80 Veterinary drug-producing companies .The total size of the industry is estimated at 2500 crores. The Allopathic \& the Vitamins segment contribute around 2100 crores. The size of Herbal/Ayurvedic segment is approx. 400 crores. Nearly 25\% of our conventional drugs are plant derivatives and many herbal drugs are being used under the traditional system of ayurveda. 
In the past two decades, the focus of the industry has been on the treatment of various diseases affecting the health and production of the livestock. In the recent past, the new trend of prevention of diseases and maintaining health of the animal has started catching up. Some of the important Ayurvedic companies who have played important role in shaping up the use of herbals for improving animal health are Indian Herbs, AyurVet Ltd., Natural Remedies, Himalaya Drug Company etc. These companies manufacture good quality herbal medicines for Veterinary use. The products of these companies are marketed internationally.

\section{Identification of animal diseases \& scope of herbal drugs}

It is a known fact that prevention is better than cure. The treatment of disease is a costly affair affecting the profits of livestock rearing. It is notable that the good quality herbal products have gained significant attraction amongst the veterinarians. These products being cost effective and efficacious are being preferred by the prescribers [13]. Looking into the efficacy and cost-effectiveness, the herbal products have become leaders in their own segments. Looking into above the Veterinary Council of India has decided to include Veterinary Ayurveda course in its curriculum.

Important segments where Ayurveda/herbal products have strength are Digestive disorders, Skin infections, Reproductive disorders, Mastitis, Lactation disorders, Metabolic disorders, Nutritional deficiency, Respiratory disorders, Ecto/Endo Parasitism, Stress \& immune disorders, Toxins control etc.

\section{Guidelines for registration of herbal formulations}

Herbal Products or Ayurvedic formulations are in vogue in practice in India for last about 4000 years. Modern medicine has gained ground for its standards, quality \& scientifically proven efficacy [11]. Still, herbal medicinal products play an important role in the health care system because of the awareness of safety of natural products coupled with new technologies available for standardization and determination of efficacy. Thus, indicating significance of the standardization.

Most of the herbal formulations consist of number of herbal ingredients resulting number of chemical moieties in the final product. This makes it very difficult and often impossible to estimate each individual ingredient herb quantity in the final formulation [14]. Therefore, efforts on polyherbal formulation should be based on solution that is more practical rather than blindly asking for the quantification of each herb or its chemical compound. Quality of any final product will be directly proportional to the quality of ingredients used. Therefore, efforts should be made to control the quality of each raw material as per standards [8].

Standardization of poly herbal formulation may include the parameters like: a. Extractive values (water, alcohol or any other solvent depending on the ingredient herbs).

b. Volatile oil content.

c. Estimation of group of compounds (like alkaloid content, saponin content, glycoside content etc. depending on the ingredient herbs).

d. TLC finger printing and estimation of any one or two marker compounds.

Apart from these parameters which indicates the quality of final products, the specification should also contain some dosage form; specific parameters like moisture content, disintegration time, average weight, weight variation, hardness, weight per $\mathrm{ml}$, total solids, dissolved solids, sieve analysis etc. Development of final product specification for any poly herbal formulation is specific for particular product and an in house effort to maintain the quality and reproducibility of efficacy of the product. This is a dynamic process and requires continuous up gradation when ever \& wherever feasible [12].

Ayurvedic products are classified into two categories viz. Classical Ayurvedic formulations and patent \& proprietary Ayurvedic products. Classical Ayurvedic formulations are prepared as per the formula \& procedures given in ancient literature approved as per the drug act. Patent \& proprietary medicines are new combination of products which developed containing herbals as active ingredients mentioned in books and folklore sources [5]. These products require licensing from the designated authority, i.e. Licensing Authority \& Director of Ayurveda of each state. There is no central body, which coordinates \& guides these individual state Ayurveda Authorities.

\section{Conclusion}

It is a fact that some of the books are on Veterinary Ayurveda have been published while several texts available in palm leaf or paper manuscripts and available in various repositories in India need to be explored. The single drug and compound formulations written in Sanskrit language need to be translated along with correlation of disease nomenclatures along with modern Veterinary science. Researches may be undertaken to evolve natural, safe and cost effective herbal products to manage the diseases of animals and to augment quality of dairy products.

\section{References}

1. British Herbal Pharmacopoeia (1983) British Herbal Medical Association, West Yorks, U.K.

2. Bradley PR (Ed) (1992) British Herbal Compendium, Vol.2, British Herbal Medicinal Association, Doreset, UK.

3. Chopra RN, Nayar SL, Chopra IC (1956) Glossary of Indian Medicinal Plants. Published by Council of Scientific \& Industrial Research, New Delhi.

4. Husain A, Virmani OP, Popli SP, Mishra L, Gupta MM, et al. (1992) Dictionary of Indian Medicinal Plants. CIMAP Publications. 
5. Kapoor LD (2001) Handbook of Ayurvedic Medicinal Plants. CRC Press, Florida, USA.

6. Jayadatta, Aswavaidyaka (1893) Shree Jivananda Vidyasagar Bhattacharya, Siddheswara Yantra, Kolkata.

7. Mangala Charana Dikshita, Karikalpalata (1927) Lakshmi Venkateshwara Press, Mumbai.

8. Nakula, Shalihotra, Khemaraja Shree Krishna Dash (1929) Venkateshwara Press, Mumbai.

9. Nakula, Aswachikitsitam, Shree Jivananda Vidyasagar Bhattacharya (1893) Siddheswara Yantra, Kolkata.
10. Nakula, Aswasastram, S. Gopalan (1952) Tanjore Maharaja Serfoji's Saraswati Mahal Library, Tanjore.

11. Palakapya M, Gajashastra, Subrahmanya Shastri MKS, Gopalan S (1958) from the Tanjore Maharaja Serfoji's Saraswati Mahal Library, Tanjore.

12. Palakapya M, Shivdatta S (1894) Hastyayurveda, Anand Ashram, Pune, India.

13. Ragho PV (1938) Pashu Chikitsa Kisan Hitakari Pustakamala Chapara from Ajanta Art Press, Prayaga, India.

14. Thakur JS (1948) Jasawant Shalihotra in Marawari language, Thakur Hari Singh, Jodhpur Devidana, Ratanu, India.

Your next submission with Juniper Publishers will reach you the below assets

- Quality Editorial service

- Swift Peer Review

- Reprints availability

- E-prints Service

- Manuscript Podcast for convenient understanding

- Global attainment for your research

- Manuscript accessibility in different formats

( Pdf, E-pub, Full Text, Audio)

- Unceasing customer service

Track the below URL for one-step submission https://juniperpublishers.com/online-submission.php 